\title{
PERBEDAAN BERKUMUR LARUTAN EKSTRAK SIWAK (Salvadora persica) TERHADAP SEKRESI SALIVA RONGGA MULUT LANJUT USIA DENGAN HIPERTENSI (HT), DIABETES MELITUS (DM) DAN TIDAK MEMILIKI PENYAKIT SISTEMIK DI PANTI SOSIAL TRESNA WERDHA GAU MABAJI GOWA TAHUN 2017
}

\author{
Syamsiah Syam, Risnayanti Anas, Andi Nelva Yunita
}

Fakultas Kedokteran Gigi Universitas Muslim Indonesia, Makassar

Email : eva.nelva@yahoo.co.id

\begin{abstract}
Background of Study: Saliva is a complex oral fluid that has an important role associated with biological processes in the oral cavity. Age changes are known to have an effect on decreasing saliva production. Likewise with systemic diseases such as hypertension and diabetes mellitus. Chemical prevention of acid imbalance in the saliva is conducted by rinsing using a siwak extract solution. Chemical content in siwak extract can increase the secretion in the saliva in the oral cavity because it has a bactericidal effect that will prevent acid production from oral bacteria. Objective of Study: To determine the difference of rinsing by using siwal extract solution on salivary secretion of the oral cavity of elderly people who have hypertension, diabetes mellitus, and do not have systemic diseases. Method: This study is pre-experiment with one group pretest and post-test design. The sample of the study was elderly people in a social housing. Also, the research used paired t-test. Result: This study shows the average change in hypertension $1.185 \mathrm{~mL} / 5$ minute with probability value 0.000 , diabates mellitus $1,358 \mathrm{~mL} / 5$ minute with probability value 0.000 , does not have systemic disease $1.057 \mathrm{~mL} / 5$ minute with probability value $0,000<0,05$ meaning there is difference. Conclusion: The difference of mouth washing of $25 \%$ extract of siwak solution to elderly salivary secretion in hypertension, diabetes mellitus and did not have systemic disease in social house of tresna werdha gau mabaji gowa.
\end{abstract}

Key words: Saliva, elderly people, Salvadora persica, hypertension, diabetes mellitus.

\section{PENDAHULUAN}

Kebersihan mulut adalah salah satu masalah penting yang perlu mendapat perhatian dalam rongga mulut. Kebersihan mulut yang baik menggambarkan keadaan kesehatan umum yang baik, sebaliknya kebersihan mulut yang buruk menggambarkan kondisi kesehatan yang buruk. ${ }^{1}$

Penggunaan obat kumur adalah salah satu cara yang dianggap cukup berhasil dalam menjaga kebersihan rongga mulut. Obat kumur bermanfaat untuk membersihkan mulut dari debris, sebagai agen antibakteri, mencegah 
Perbedaan berkumur larutan ekstrak siwak terhadap sekresi saliva rongga mulut lanjut usia dengan hipertensi, diabetes melitus dan tidak memiliki penyakit sistemik di Panti Sosial Tresna Werdha Gau Mabaji Gowa tahun 2017

dan mengurangi aktifitas mikroorganisme plak serta mengurangi aktifitas mikroorganisme yang menyebabkan bau mulut sehingga meningkatkan kesehatan gigi dan mulut. Aktivitas berkumur merupakan pencegahan penyakit rongga mulut secara kimiawi dapat di lakukan untuk mencegah ketidakseimbangan asam di dalam rongga mulut. ${ }^{2.3}$

Saliva merupakan cairan mulut yang kompleks terdiri dari campuran sekresi kelenjar saliva mayor dan minor di dalam rongga mulut. Kontribusi volume terbesar saliva secara kuantitatif diberikan oleh kelenjar parotis $(60-65 \%)$, submandibularis (20$30 \%)$, dan sublingualis (2-5\%). Sekresi saliva normal adalah $800-1500 \mathrm{~mL} /$ hari. Pada orang dewasa laju aliran saliva normal yang distimulasi mencapai 1-3 $\mathrm{mL} /$ menit. Rata-rata terendah mencapai $\quad 0,7-1 \quad \mathrm{~mL} / \mathrm{menit}$. Pada keadaan hiposalivasi ditandai dengan laju aliran saliva yang lebih rendah dari 0,7-1 $\mathrm{mL} /$ menit. Laju aliran saliva normal tanpa adanya stimulasi berkisar 0,25-0,35 $\mathrm{mL} / \mathrm{menit}$, dengan rata-rata terendah $0,1-0,25 \mathrm{~mL} /$ menit dan pada keadaan hiposalivasi laju aliran saliva dalam keadaan normal antara 5,6-7,0 dengan rata-rata $\mathrm{pH} 6,7.4 .5$
Perubahan umur diketahui dapat berpengaruh terhadap penurunan produksi saliva. Akibatnya hal ini disebabkan karena terjadi penurunan fungsi glandula parenkim saliva. Namun, seiring dengan meningkatnya usia, terjadi proses aging. Terjadi perubahan dan kemunduran fungsi kelenjar saliva, kelenjar parenkim hilang yang digantikan oleh jaringan lemak dan penyambung, lining sel duktus intermediate mengalami atropi. Keadaan ini mengakibatkan pengurangan penurunan produksi saliva. Selain itu, penyakit sistemik seperti hipertensi dan diabetes mellitus yang diderita pada lanjut usia aliran saliva mengalami penurunan yang berakibat terjadinya keluhan xerostomia. Di samping itu juga terjadi perubahan komposisi saliva yang disebabkan oleh gangguan sekresi glandula submaksilaris dan parotis sebagai akibat dari kelainan hormonal. 6.5

Berdasarkan observasi awal yang telah kami lakukan sebelumnya di Panti Sosial Tresna Werdha Gau Mabaji, hampir keseluruhan dari populasi lanjut usia di tempat tersebut memiliki penyakit sistemik khususnya diabetes mellitus, hipertensi dan ada juga yang tidak memiliki penyakit 
Perbedaan berkumur larutan ekstrak siwak terhadap sekresi saliva rongga mulut lanjut usia dengan hipertensi, diabetes melitus dan tidak memiliki penyakit sistemik di Panti Sosial Tresna Werdha Gau Mabaji Gowa tahun 2017

sistemik. Maka dengan hal ini lanjut usia di tempat tersebut memiliki berbagai tipe dalam membandingkan sekresi saliva rongga mulut lanjut usia. konsumsi obat-obatan seperti antidepresan, antihipertensi, antihistamin dan antipsikotik. akan menyebabkan menurunnya sekresi pada glandula saliva mayor. Maka dengan hal ini menyebabkan lanjut usia tersebut tidak mendapatkan fungsi saliva sebagai proteksi dan akan meningkatkan risiko untuk mengalami komplikasi hipofungsi dari glandula saliva.

Pencegahan terhadap ketidakseimbangan asam pada saliva dapat dilakukan secara mekanis maupun kimiawi, dengan larutan kumur yang dinilai lebih murah, efisien, ramah lingkungan, serta memiliki efek samping yang minimal adalah larutan kumur dari bahan alami, salah satunya yaitu larutan ekstrak siwak (Salvadora persica). World Health Organization (1987) merekomendasikan penggunaan siwak sebagai alat yang efektif untuk kesehatan mulut, dengan tindakan mekanik serat kayu lunak dan aksi terapetik kandungan kimianya. Ekstrak siwak memiliki efek antisbakterial, efektif dalam melawan bakteri yang berperan pada pembentukan plak gigi, sehingga dengan penurunan bakteri plak, maka $\mathrm{pH}$ saliva juga akan meningkat. Kandungan minyak atsiri di dalam batang siwak seperti benzyl isothiocyante dapat meningkatkan sekresi pada saliva di dalam rongga mulut. Peningkatan produksi saliva ini akan meningkatkan aktivitas buffer bikarbonat saliva sehingga $\mathrm{pH}$ saliva juga akan meningkat. ${ }^{2.3 .7}$

\section{METODE PENELITIAN}

\section{Metode dan Rancangan Penelitian}

Metode penelitian ini adalah penelitian studi eksperimental pra eksperiment dengan satu kelompok menggunakan rancangan one group pretest and posttest design.

\section{Prosedur Penelitian}

Batang siwak dicuci hingga bersih dan dipotong sehingga menjdi bagian kecil-kecil, setelah itu di timbang sesuai yang dibutuhkan yaitu dalam bentuk larutan ekstrak siwak 25\% dibutuhkan $125 \mathrm{gr}$ batang siwak, kemudian batang siwak dimasukkan dalam gelas kimia $1000 \mathrm{~mL}$ dan ditambahkan aqua pro injeksi sebanyak $500 \mathrm{~mL}$. setalah itu dimasukkan dalam panji infusa dan dipanaskan pada suhu 90-95 ${ }^{\circ} \mathrm{C}$ dan didiamkan selama 15 menit. Setelah 15 menit, siwak hasil 
Perbedaan berkumur larutan ekstrak siwak terhadap sekresi saliva rongga mulut lanjut usia dengan hipertensi, diabetes melitus dan tidak memiliki penyakit sistemik di Panti Sosial Tresna Werdha Gau Mabaji Gowa tahun 2017

infusa disaring. sehingga didapatkan larutan ektrak siwak konsentrasi 25\%.

Populasi penelitian adalah lanjut usia yang terdapat di Panti Sosial Tresna Werdha Gau Mabaji Gowa.
Metode pengambilan sampel dilakukan dengan teknik total sampling, yaitu pengambilan sampel yang dilakukan sesuai dengan kriteria inklusi dan ekslusi penelitian.

\section{HASIL PENELITIAN}

Tabel 1. Rata-rata sekresi saliva sebelum berkumur larutan ekstrak siwak, terhadap hipertensi, Diabetes mellitus dan tidak memiliki penyakit sistemik.

\begin{tabular}{clc}
\hline Penyakit & \multicolumn{1}{c}{ Sekresi Saliva (Pre Test) } \\
\hline \multirow{3}{*}{ Hipertensi } & Mean & 3,329 \\
& $N$ & 14 \\
& Std. Deviation &, 2494 \\
& Minimum & 3,0 \\
& Maximum & 3,7 \\
\hline & Mean & 3,517 \\
& $N$ & 12 \\
& Std. Deviation &, 2657 \\
& Minimum & 3,2 \\
& Maximum & 4,0 \\
\hline \multirow{3}{*}{ Tidak Ada Penyakit Sistemik } & Mean & 3,321 \\
& Std. Deviation & 14 \\
& Minimum &, 3118 \\
& Maximum & 3,0 \\
& & 4,0 \\
\hline
\end{tabular}

(Sumber; Data Primer, 2018)

Tabel 2. Rata-rata sekresi saliva sesudah berkumur larutan ekstrak siwak terhadap hipertensi, diabetes mellitus dan tidak memiliki penyakit sistemik.

\begin{tabular}{clc}
\hline Penyakit & & Sekresi Saliva (Post test) \\
\hline \multirow{3}{*}{ Hipertensi } & Mean & 4,514 \\
& $N$ & 14 \\
& Std. Deviation & 4276 \\
& Minimum & 4,0 \\
& Maximum & 5,1 \\
\hline \multirow{2}{*}{ DM } & Mean & 4,875 \\
& $N$ & 12 \\
& Std. Deviation & 4003 \\
& Minimum & 4,0 \\
& Maximum & 5,3 \\
\hline \multirow{2}{*}{ Tidak Ada Penyakit Sistemik } & Mean & 4,379 \\
& N & 14 \\
& Std. Deviation &, 3867 \\
& Minimum & 4,0 \\
& Maximum & 5,1 \\
\hline
\end{tabular}

(Sumber; Data Primer, 2018) 
Perbedaan berkumur larutan ekstrak siwak terhadap sekresi saliva rongga mulut lanjut usia dengan hipertensi, diabetes melitus dan tidak memiliki penyakit sistemik di Panti Sosial Tresna Werdha Gau Mabaji Gowa tahun 2017

Tabel 3. Perbedaan sekresi saliva sebelum dan sesudah berkumur larutan ekstrak siwak terhadap hipertensi, diabetes mellitus dan tidak memiliki penyakit sistemik.

\begin{tabular}{|c|c|c|c|c|c|}
\hline \multirow[b]{2}{*}{ Penyakit } & & \multirow[b]{2}{*}{$\mathbf{n}$} & \multicolumn{2}{|c|}{ Sekresi saliva } & \multirow[b]{2}{*}{ p } \\
\hline & & & Mean \pm SD & $\begin{array}{c}\text { Perubahan } \\
\text { Mean } \pm \text { SD }\end{array}$ & \\
\hline \multirow{2}{*}{ Hipertensi } & Pre test & 14 & $3,329 \pm 0,249$ & \multirow{2}{*}{$1,185 \pm 0,244$} & \multirow{2}{*}{0,000} \\
\hline & Post test & 14 & $4,514 \pm 0,427$ & & \\
\hline \multirow{2}{*}{ DM } & Pre test & 12 & $3,517 \pm 0,265$ & \multirow{2}{*}{$1,358 \pm 0,290$} & \multirow{2}{*}{0,000} \\
\hline & Post test & 12 & $4,875 \pm 0,400$ & & \\
\hline \multirow{2}{*}{$\begin{array}{l}\text { Tidak Memiliki Penyakit } \\
\text { Sistemik }\end{array}$} & Pre test & 14 & $3,321 \pm 0,311$ & \multirow{2}{*}{$1,057 \pm 0,174$} & \multirow{2}{*}{0,000} \\
\hline & Post test & 14 & $4,379 \pm 0,386$ & & \\
\hline
\end{tabular}

(Sumber; Data Primer, 2018)

Tabel 4. Perbedaan perubahan sekresi saliva antara hipertensi, diabetes mellitus dan tidak memiliki penyakit sistemik.

\begin{tabular}{cccc}
\hline (I) Penyakit & (J) Penyakit & $\begin{array}{c}\text { Perubahan sekresi saliva } \\
\text { Mean } \pm \text { SD }\end{array}$ & Sig. \\
\hline Hipertensi & DM & $0,172 \pm 0,093$ & 0,170 \\
\hline DM & $\begin{array}{c}\text { Tidak memiliki } \\
\text { Penyakit Sistemik }\end{array}$ & $0,301 \pm 0,937$ & 0,007 \\
\hline $\begin{array}{c}\text { Tidak memiliki Penyakit } \\
\text { Sistemik }\end{array}$ & Hipertensi & $0,128 \pm 0,090$ & 0,337 \\
\hline
\end{tabular}

(Sumber; Data Primer, 2018)

\section{PEMBAHASAN}

Berdasarkan hasil penelitian mengenai perbedaan berkumur larutan ekstrak siwak (salvadora persica) terhadap sekresi saliva rongga mulut lanjut usia, hipertensi (HT), diabetes mellitus (DM), dan tidak memiliki penyakit sistemik di Panti Sosial Tresna Werdha Gau Mabaji Gowa tahun 2017.

Total sampel yang terkumpul yakni 40 yang didapat sesuai dengan perhitungan sampel. Prosedur eksperimen ini berjalan tanpa adanya keluhan efek samping yang mungkin dirasakan oleh subjek penelitian. Saat ditanyakan apakah pada saat berkumur menyebabkan rasa tidak nyaman, atau rasa tidak enak, $100 \%$ dari subjek penelitian menjawab tidak ada.

Nilai rerata sekresi saliva pada data hipertensi sebelum berkumur menggunakan larutan ekstrak siwak, dengan jumlah sampel 14 orang, 5 sampel laki-laki dan 9 sampel perempuan yaitu $3,329 \mathrm{ml} / 5$ menit memiliki standar deviasi 0,249m/ $/ 5$ menit dengan nilai minimum $3,0^{\mathrm{ml}} / 5$ menit dan maximum $3,7^{\mathrm{ml}} / 5$ menit. 
Perbedaan berkumur larutan ekstrak siwak terhadap sekresi saliva rongga mulut lanjut usia dengan hipertensi, diabetes melitus dan tidak memiliki penyakit sistemik di Panti Sosial Tresna Werdha Gau Mabaji Gowa tahun 2017

Pada kondisi hipertensi dengan tekanan darah sebesar 140/90 $\mathrm{mmHg}$ maka aliran darah yang menuju organ vital akan berkurang sebagai akibat resistensi pembuluh darah yang menuju ke organ tersebut meningkat. ${ }^{8}$ Hal demikian mengakibatkan suplai darah menuju organ yang divaskularisasinya berkurang sehingga kecepatan sekresi kelenjar saliva menjadi menurun.

Berdasarkan hasil penelitian Moxey (2003), 58,8\% lansia mengkonsumsi obat-obatan kardiovaskuler, termasuk obat antihipertensi. Populasi lansia memiliki risiko lebih tinggi terhadap masalah yang timbul berkaitan dengan konsumsi obat-obatan. Hal ini terjadi karena adanya perubahan fisiologis dan biologis tubuh akibat proses menua. Perubahan fisiologis yang terjadi pada usia lanjut menyebabkan terjadinya perubahan konsentrasi obat yang beredar dalam tubuh, waktu eliminasi, respon organ, dan interaksi. Perubahan system biologis pada usia lanjut mempengaruhi proses interaksi molekul obat, yang pada akhirnya akan mempengaruhi kemanfaatan klinik dan keamanan farmakoterapi. ${ }^{9}$ Nilai rerata sekresi saliva pada data diabetes melitus sebelum berkumur menggunakan larutan ekstrak siwak, dengan jumlah sampel 12 orang, 4 sampel laki-laki dan 8 sampel perempuan yaitu $3,517 \mathrm{ml} / 5$ menit memiliki standar deviasi $0,265^{\mathrm{ml}} / 5$ menit dengan nilai minimum $3,2 \mathrm{ml} / 5$ menit dan maximum 4,0 $\mathrm{ml} / 5$ menit.

Pada penyakit diabetes mellitus (DM) merupakan penyakit metabolik yang ditandai dengan kadar glukosa dalam darah yang tinggi karena terdapat masalah pada sekresi insulin, kerja insulin, atau keduanya. Semakin lama seseorang menderita diabetes mellitus maka komplikasi dalam rongga mulut seperti hiposalivasi dan xerostomia akan lebih banyak muncul. Hal ini disebabkan hubungan level kadar glukosa darah pada sampel diabetes mellitus yang berhubungan dengan kejadian penurunan sekresi saliva. Adanya peningkatan diuresis yang berhubungan dengan penurunan cairan ekstraseluler karena adanya hiperglikemia sehingga berefek langsung pada produksi saliva. Beberapa faktor fisiologis juga dapat mempengaruhi dari fungsi saliva pada sampel diabetes mellitus (DM). ${ }^{9}$

Nilai rerata sekresi saliva pada data tidak memiliki penyakit sistemik sebelum berkumur menggunakan larutan ekstrak siwak, dengan jumlah 
Perbedaan berkumur larutan ekstrak siwak terhadap sekresi saliva rongga mulut lanjut usia dengan hipertensi, diabetes melitus dan tidak memiliki penyakit sistemik di Panti Sosial Tresna Werdha Gau Mabaji Gowa tahun 2017

sampel 14 orang, 5 sampel laki-laki dan 9 sampel perempuan yaitu $3,321 \mathrm{ml} / 5 \mathrm{menit}$ memiliki standar deviasi $0,311 \mathrm{ml} / 5$ menit dengan nilai minimum $3,0 \mathrm{ml} / 5$ menit dan maximum $4,0 \mathrm{~m} / 5$ menit.

Pada dasarnya produksi saliva setiap orang bervariasi, tetapi pada lanjut usia risiko untuk mengalami hiposalivasi dan gejala xerostomia sering ditemukan pada usia lanjut. Keadaan ini disebabkan oleh adanya perubahan atropi pada kelenjar saliva sesuai dengan pertambahan umur yang akan menurunkan produksi saliva dan mengubah komposisinya sedikit. Seiring dengan meningkatnya usia, terjadi proses aging. Terjadi perubahan dan kemunduran fungsi kelenjar saliva, dimana kelenjar parenkim hilang yang digantikan oleh jaringan lemak dan penyambung, lining sel duktus intermediate mengalami atropi. Keadaan ini mengakibatkan pengurangan jumlah aliran saliva. ${ }^{9.10}$

Nilai rerata sekresi saliva pada data hipertensi sesudah berkumur menggunakan larutan ekstrak siwak, dengan jumlah sampel 14 orang, 5 sampel laki-laki dan 9 sampel perempuan yaitu $4,514 \mathrm{ml} / 5$ menit memiliki standar deviasi $0,427 \mathrm{ml} / 5$ menit dengan nilai minimum $4,0 \mathrm{ml} / 5$ menit dan maximum $5,1 \mathrm{ml} / 5$ menit. Nilai rerata sekresi saliva pada data diabetes melitus sesudah berkumur menggunakan larutan ekstrak siwak, dengan jumlah sampel 12 orang, 4 sampel laki-laki dan 8 sampel perempuan yaitu $4,875^{\mathrm{ml}} / 5$ menit memiliki standar deviasi $0,400 \mathrm{ml} / 5$ menit dengan nilai minimum $4,0 \mathrm{ml} / 5$ menit dan maximum 5,3 $\mathrm{m} / 5$ menit. Nilai rerata sekresi saliva pada data tidak memiliki penyakit sistemik sesudah berkumur menggunakan larutan ekstrak siwak, dengan jumlah sampel 14 orang, 5 sampel laki-laki dan 9 sampel perempuan yaitu $4,379 \mathrm{ml} / 5$ menit memiliki standar deviasi $0,386^{\mathrm{ml}} / 5$ menit dengan nilai minimum $4,0 \mathrm{ml} / 5$ menit dan maximum $5,1 \mathrm{ml} / 5$ menit.

Perubahan yang terjadi pada sekresi saliva setelah berkumur menggunakan larutan ekstrak siwak karna adanya kandungan minyak atsiri pada batang siwak seperti benzyl isothiocyante dapat meningkatkan sekresi pada saliva di dalam rongga mulut, Peningkatan aliran saliva ini akan menigkatkan aktivitas buffer bikarbonat saliva sehingga Sekresi saliva juga akan meningkat. Efek bakterisida pada siwak dihasilkan oleh kandungan thiocyanate ( $\left.\mathrm{SCN}^{-}\right)$dan alkaloid yang merupakan salvadorine sehingga mengatur $\mathrm{pH}$ rongga mulut menstimulasi gingiva. Pada ekstrak 
Perbedaan berkumur larutan ekstrak siwak terhadap sekresi saliva rongga mulut lanjut usia dengan hipertensi, diabetes melitus dan tidak memiliki penyakit sistemik di Panti Sosial Tresna Werdha Gau Mabaji Gowa tahun 2017

siwak terkandung klorida yang tinggi dan kalsium yang memperngaruhi peningkatan Sekresi saliva rongga mulut.

Pada penelitian ini di lakukan oleh Endarti, Fauzia, Zuliana (2007) yang menunjukkan bahwa kandungan minyak esensial di dalam siwak dapat merangsang sekresi saliva, sehingga penurunan $\mathrm{pH}$ plak dapat dihambat karena di dalam saliva ditemukan adanya buffer bikarbonat yang merupakan pertahanan efektif terhadap produksi asam dari bakteri kariogenik.

Perbedaan sekresi saliva sebelum dan sesudah berkumur larutan ekstrak siwak pada data hipertensi yaitu $1,185^{\mathrm{ml}} / 5$ menit dengan nilai $P$ pada perbedaan berkumur larutan ekstrak siwak sebelum dan sesudah yaitu 0,000 dari hasil uji statistik menggunakan uji $t$ berpasangan paired sample t-test diperoleh nilai probabilitas atau sig. (2tailed) pada data hipertensi,diabetes mellitus dan tidak memiliki penyakit sistemik sebesar sig. (2-tailed) $0,000<$ 0,05 , dengan demikian diputuskan bahwa $\mathrm{H}_{\mathrm{o}}$ di tolak dan $\mathrm{H}_{\mathrm{a}}$ diterima yang artinya terdapat perbedaan yang signifikan antara hasil sebelum berkumur larutan ekstrak siwak dan sesudah berkumur larutan ekstrak siwak. Pada penelitian ini didapatkan adanya perbedaan berkumur larutan ekstrak siwak terhadap sekresi saliva pada lanjut usia hipertensi, diabetes melitus dan tidak memiliki penyakit sistemik pada panti sosial tresna werdha gau mabaji gowa. Perbedaan sekresi saliva, dikarenakan dengan berkumur larutan ekstrak siwak akan menyebabkan stimulus mekanis dan dapat merangsang peningkatan sekresi saliva, sedangkan kandungan yang terkandung di dalam batang siwak merupakan stimulus kimiawi yang juga dapat meningkatkan sekresi saliva, Bahan makanan yang sangat cepat berpengaruh terhadap sekresi saliva dalam rongga mulut yaitu bahan makanan yang dapat menstimulasi sekresi saliva tersebut, salah satunya adalah yang memiliki rasa asam yang diterima oleh saraf dalam mulut sangat kuat menstimulasi sekresi saliva. Rasa dari obat kumur sodium bikarbonat adalah asam, inilah mengapa larutan ekstrak siwak 25\% dapat sangat kuat menstimulasi sekresi saliva dalam rongga mulut.

Perbedaan perubahan sekresi saliva antara diabetes mellitus vs tidak memiliki penyakit sistemik karna menghasilkan nilai $p$ atau sig 0,007 < 0,05 sehingga pada diabetes mellitus 
Perbedaan berkumur larutan ekstrak siwak terhadap sekresi saliva rongga mulut lanjut usia dengan hipertensi, diabetes melitus dan tidak memiliki penyakit sistemik di Panti Sosial Tresna Werdha Gau Mabaji Gowa tahun 2017

memiliki perubahan sekresi saliva yang lebih tinggi pada, dibandingkan dengan data lainnya.

$$
\text { Pada penelitian ini }
$$

perbandingan antara diabetes melitus dan tidak memiliki penyakit sistemik menghasilkan perubahan yg lebih tinggi pada diabetes melituss karna Diabetes mellitus dapat mengakibatkan perubahan hormonal, mikrovaskular dan neuronal yang dapat mempengaruhi fungsi dari berbagai organ. Perubahan mikrovaskular dapat mempengaruhi kemampuan kelenjar saliva dalam merespon stimulasi neural atau hormonal. Sekresi saliva juga dikontrol oleh sistem saraf autonom sehingga kemungkinan dengan adanya neuropati dapat menggangu kemampuan seseorang dalam merespon dan menstimulasi kelenjar saliva, serta mengubah aliran dan komposisi saliva. Adanya penggantian fungsi jaringan oleh jaringan adiposa pada kelenjar saliva mayor dapat mengurangi jumlah dan kuantitas sekresi saliva. Hal tersebut dapat diperparah dengan adanya efek samping obat-obatan, gangguan penyakit lokal pada kelenjar saliva, serta faktor imun dan kekebalan tubuh yang mulai menurun seiring dengan pertambahan usia. $^{10}$ Menurut penelitian sebelumnya Patricia (2008) laju aliran saliva dibagi menjadi tiga, yaitu normal, rendah dan sangat rendah. Laju aliran saliva normal pada saat tidak distimulasi sekitar 0,25-0,3 $\mathrm{ml} /$ menit, rendah apabila laju aliran saliva $0,1-0,25 \mathrm{ml} /$ menit dan sangat rendah apabila laju aliran saliva $<0,1$ $\mathrm{ml} / \mathrm{menit}$. Seseorang dikatakan xerostomia apabila laju aliran saliva tidak distimulasi (USFR) $<0,1 \mathrm{ml} /$ menit. Sedangkan pada penelitian sebelumnya diabetes mellitus (DM) yang mengalami hiposalivasi dengan laju aliran saliva rendah paling banyak ditemukan. Hasil ini sesuai dengan penelitian yang telah dilakukan oleh Vasconcelos dkk. bahwa pada pasien DM yang diperiksa dan mengalami hiposalivasi memiliki persentase yang cukup tinggi yaitu $45 \%$ dibandingkan dengan xerostomia yang hanya sekitar $12,5 \%$.

Pada hasil penelitian ini membuktikan bahwa berkumur menggunakan larutan ekstrak siwak $25 \%$ dapat meningkatkan sekresi saliva pada penderita hipertensi, diabetes mellitus, dan tidak memiliki penyakit sistemik.

\section{KESIMPULAN}

1. Hasil rata-rata sekresi saliva rongga mulut lanjut usia di panti Sosial 
Perbedaan berkumur larutan ekstrak siwak terhadap sekresi saliva rongga mulut lanjut usia dengan hipertensi, diabetes melitus dan tidak memiliki penyakit sistemik di Panti Sosial Tresna Werdha Gau Mabaji Gowa tahun 2017

Tresna Werdha Gau Mabaji Gowa sebelum berkumur larutan ekstrak siwak 25\% (Salvadora Persica) yaitu Hipertensi (HT) 3,329m/ $/ 5$ menit, diabetes melitus (DM) 3,517 ml/5menit, dan tidak memiliki penyakit sistemik $3,321^{\mathrm{ml} / 5 \text { menit. }}$

2. Hasil rata-rata sekresi saliva rongga mulut lanjut usia hipertensi (HT) di panti Sosial Tresna Werdha Gau Mabaji Gowa sesudah berkumur larutan ekstrak siwak 25\% (Salvadora Persica) yaitu hipertensi (HT) $4,514 \mathrm{ml} / 5$ menit, diabetes melitus (DM) $4,875^{\mathrm{m} /} / 5$ menit, dan tidak memiliki penyakit sistemik $4,379 \mathrm{ml} / 5$ menit.

3. Perbedaan sekresi saliva sebelum dan sesudah berkumur larutan ekstrak siwak pada data hipertensi yaitu $1,185^{\mathrm{ml} /} / 5$ menit dengan nilai $P$ pada perbedaan berkumur larutan ekstrak siwak sebelum dan sesudah yaitu 0,000 dari hasil uji statistik menggunakan uji $t$ berpasangan paired sample t-test diperoleh nilai probabilitas atau sig. (2-tailed) pada data hipertensi,diabetes mellitus dan tidak memiliki penyakit sistemik sebesar sig. (2-tailed) 0,000 <0,05, dengan demikian diputuskan bahwa $\mathrm{H}_{\circ}$ di tolak dan $\mathrm{H}_{\mathrm{a}}$ diterima yang artinya terdapat perbedaan yang signifikan antara hasil sebelum berkumur larutan ekstrak siwak dan sesudah berkumur larutan ekstrak siwak.

4. Perbedaan perubahan sekresi saliva antara diabetes mellitus terhadap tidak memiliki penyakit sistemik karna menghasilkan nilai $p$ atau sig 0,007 $<0,05$ sehingga pada diabetes mellitus memiliki perubahan sekresi saliva yang lebih tinggi pada, dibandingkan dengan data lainnya.

\section{DAFTAR PUSTAKA}

1. Putri Deby Knaia Tri, Basuni, C. Gambaran Indeks kebersihan Mulut Berdasarkan Tingkat Pendidikan Masyarakat di Desa Gunting Ujung Kabupaten Banjar. Dentino Jurnal Kedokteran Gigi. 2014:Vol.2 No.1

2. Kasuma Nila, Adzakiyah Tiara, DKK., 2015. Pengaruh berkumur dengan larutan ekstrak siwak (salvadora persica) terhadap ph saliva rongga mulut., Fakultas kedokteran gigi Universitas Andalas., Vol.2 No.1

3. Kusumari Nila, Santoso-Oedijani, DKK. Pengaruh Larutan Ekstrak Siwak (Salvadora Persica) terhadap Streptococcus Mutans : Studi In Vitro dan Invivo., 2012:Vol.46 No.3

4. Santoso Oedijono, Ismail Ade, DKK. Pengaruh Konsumsi Keju Cheddas 10 gram terhadap Ph Saliva-Studi terhadap Mahasiswa Fakultas Kedokteran Gigi Universitas Islam Sultan Agung Semarang. Dental Journal. 2014: Vol.1 No.1. 
Perbedaan berkumur larutan ekstrak siwak terhadap sekresi saliva rongga mulut lanjut usia dengan hipertensi, diabetes melitus dan tidak memiliki penyakit sistemik di Panti Sosial Tresna Werdha Gau Mabaji Gowa tahun 2017

5. Samad rasmidar, Riskayanty, D.R, DKK. Profil Kandungan Unsur Anorganik dan Organic Saliva pada Keadaan Usia Lanjut. Fakultas Universitas Hasanuddin. Dentofasial. 2014: Vol.13 No.1.

6. Kidah Siti, L Maharani, DKK. Gambaran Klinis Kelainan Mukosa Rongga Mulut pada Lansia di Panti Sosial Tresna Werdha Budi sejahtera Banjarmasing., Dentino. Jurnal Kedokteran Gigi., 2014: Vol. 2 No 1

7. Khatimah I, H., Pradanta Y, E ., DKK. Hubungan Kadar $\mathrm{pH}$ dan Volume Saliva terhadap Indeks Karies Masyarakat Menginang Kecamatan Lokpaikat Kabupaten Tapin., Fakultasa Kedokteran Gigi
Universita Lambung Mangkurat. Banjarmasing., 2016: Vol.1 No 2

8. Safar dan Lacolly. Disturbance of macro and micro ciraltion : relations with pulse pressure and cardiac organ damage., Am, Physiology. 2007: 293

9. Humairo Inayaty, Apriasari laillyza Maharani, Studi deskripsi laju aliran saiva pada pasien diabetes mellitus di RSUD Ulin Banjarmasin., Departemen ilmu penyakit mulut., Banjarmasin., 2014: Vol.63 No.1

10. Hasibun Sayuti, Keluhan Mulut Kering Di Tinjau dari Faktor Penyebab Manifestasi dan Penanggulangannya., Universitas Sumatera Utara., Sumatera. 2002. 